\title{
Effects of resource availability on condensed tannins and nitrogen in two Quercus species differing in leaf life span
}

\author{
Marc ESTIARTE $^{\mathrm{a} *}$, Montserrat DE CASTRO $^{\mathrm{b}}$, Josep Maria ESPELTA $^{\mathrm{b}}$ \\ ${ }^{a}$ Unitat d'Ecofisiologia CSIC-CEAB-CREAF, CREAF (Centre de Recerca Ecològica i Aplicacions Forestals), Universitat Autònoma de Barcelona, \\ 08193 Bellaterra, Catalonia, Spain \\ ${ }^{\mathrm{b}}$ Centre de Recerca Ecològica i Aplicacions Forestals (CREAF), Universitat Autònoma de Barcelona, 08193 Bellaterra, Catalonia, Spain
}

(Received 2 June 2006; accepted 8 November 2006)

\begin{abstract}
Seedlings of Quercus ilex and Q. cerrioides, an evergreen and a winter-deciduous oak co-occurring in western-Mediterranean forests, were grown at two light regimes ( 8 and $36 \%$ of photosynthetically active radiation), at two water regimes (500 and $800 \mathrm{~mm}$ ) and with two nutrient availabilities (standard substrate and 7\% increase in soil N). The concentrations of soluble condensed tannins (CT) and nitrogen in the leaves were analyzed to test the phenotypic plasticity of these commonly related parameters in two con-generic species with contrasting leaf habit. $Q$. ilex contains seven times more CT and a few less $\mathrm{N}$ than $Q$. cerrioides. Light increased CT, whereas neither fertilization nor water had an effect on CT. N concentration was decreased by light, increased by fertilization and not affected by water treatment. Plant growth was increased by light but not affected by fertilization or water treatment. CT were negatively correlated with $\mathrm{N}$ concentration. CT of the evergreen species exhibited greater plasticity than the deciduous one as reflected by a steeper negative correlation among nitrogen and CT concentrations in $Q$. ilex. Given the antiherbivory activity of CT, this implies that in less shaded environments, e.g. canopy aperture by disturbances, leaf tissue quality for herbivores will be much more reduced in $Q$. ilex than in $Q$. cerrioides. Higher leaf CT in $Q$. ilex and its higher plasticity to light availability may explain the higher browsing by sheep in $Q$. cerrioides than in $Q$. ilex resprouts, as well as the low recruitment rates of seedlings of the former species, reported in other studies.
\end{abstract}

condensed tannins / deciduous / evergreen / Quercus ilex / Quercus cerrioides / herbivory

\begin{abstract}
Résumé - Effets de la disponibilité de la ressource sur les tanins condensés et l'azote chez deux espèces de Quercus différentes pour la durée de vie de leurs feuilles. Des semis de Quercus ilex et Quercus cerrioides, une espèce sempervirente et une espèce décidue co-existantes dans les forêts méditerranéennes occidentales, ont été élevés sous deux régimes lumineux (8 et $36 \%$ de PAR), deux régimes d'alimentation hydrique (500 et 800 mm) et avec deux niveaux d'alimentation nutritionnelle (substrat standard et substrat avec une augmentation d'azote de $7 \%$ ). Les concentrations des tanins solubles condensés (CT) et d'azote des feuilles ont été analysées pour tester la plasticité phénotypique de ces paramètres couramment rapportés chez deux espèces de même genre ayant des types différents de feuilles. Quercus ilex contient 7 fois plus de CT et un peu moins d'azote que Quercus cerrioides. La lumière accroît CT alors que ni la fertilisation ni l'eau ont eu un effet sur CT. La concentration en azote a diminué avec l'augmentation de la lumière, elle a été augmentée par la fertilisation et n'a pas été affectée par le niveau d'alimentation hydrique. La croissance des semis a été augmentée par l'augmentation du PAR mais n'a pas été affectée par la fertilisation ou le niveau d'alimentation en eau. CT a été corrélée avec la concentration en azote. La CT des espèces sempervirentes présente une plus grande plasticité que les espèces décidues comme cela est reflété par une plus forte corrélation négative entre les concentrations d'azote et de CT chez Quercus ilex. Etant donné l'activité antiherbivore de CT, cela implique que dans les environnements moins ombragés, par exemple dans les ouvertures de la canopée, la qualité des tissus foliaires sera plus diminuée chez Quercus ilex, que chez Quercus cerrioides. Une CT plus élevée chez Quercus ilex, et sa plasticité plus grande à la lumière peuvent expliquer un broutage plus important des rejets par les moutons chez Quercus cerrioides que chez Quercus ilex, de même que le faible taux de recrutement de semis de la première espèce qui est rapportée dans d'autres études.
\end{abstract}

tanins condensés / décidu / sempervirent / Quercus ilex / Quercus cerrioides / herbivore

\section{INTRODUCTION}

Condensed tannins (CT) are secondary compounds of polyphenolic nature derived from phenylpropanoid precursors. They occur in the leaves of all ferns and gymnosperms and about half the families, the woody members, of angiosperms [23]. CT are considered plant chemical defenses against pathogens and herbivores [6]. Antiherbivory activity is based on its negative effects on palatability and digestibility due to its ability to bind to proteins [42].

* Corresponding author: m.estiarte@ creaf.uab.cat
$\mathrm{CT}$, as well as other phenolic compounds, are carbonbased secondary compounds because they do not contain nitrogen atoms. The concentration of carbon-based secondary compounds has been related to the availability of resources both from an evolutionary [15] and from a phenotypic point of view [7, 24, 34]. From a phenotypic point of view, the Carbon Nutrient Balance [7] hypothesis relates carbon-based secondary compounds concentration to the balance between carbon and nitrogen in the plant and predicts that plants allocate more carbon to carbon-based secondary compounds when carbon accumulates in excess of growth demands (i.e. under nutrient deficiency, high light and elevated $\mathrm{CO}_{2}$ ). Similarly, 
the Growth Differentiation Balance hypothesis [24] extends the carbon nutrient balance hypothesis, and considers that any environmental condition that affects photosynthesis (carbon source) and growth (carbon sink) with different intensity will affect the relative carbon pool available for allocation to carbon-based compounds. According to growth differentiation balance hypothesis, conditions that limit growth more than photosynthesis, such as nutrient limitation or moderate drought, increase the carbon available for allocation to carbonbased secondary compounds.

Koricheva et al. [28] conducted a meta-analysis of 147 species to test the carbon nutrient balance and growth differentiation balance hypothesis and concluded that plant responses to nitrogen fertilization and shading were consistent with the predictions of both hypotheses in terms of pooled carbon-based secondary compounds, but among biosynthetically distinct groups of carbon-based secondary compounds, only concentrations of phenylpropanoid-derived compounds, such as CT, changed as predicted, as was also described in Peñuelas and Estiarte's [34] review.

Quercus ilex and Q. cerrioides - a species from the Quercus humilis group with several probable introgressions from other deciduous Quercus - are two very abundant oaks in the western rim of the Mediterranean Basin. Mediterranean ecosystems are characterized by the variability in resources availability (water, nutrients and light). The Mediterranean climate is characterized by dry and warm summers and by a high interannual variability in precipitation. The soils in Mediterranean ecosystems have low nutrient availability which limits plant growth [41, 43]. The heterogeneity in Mediterranean ecosystems overlaps with a high frequency of disturbances. Fire and herbivory, as two of the main disturbances in the Mediterranean-Basin, play a crucial role in determining an heterogeneous structure of Mediterranean-type communities [36]. Consequently, the amount of light available in forest understory can vary greatly due to the different degree of canopy closure depending on forest cover and canopy structure [47].

Specific plant response to environmental heterogeneity plays a key role in the coexistence or substitution among forest tree species. Plants adjust their architecture, physiology and biomass distribution in order to acquire the limiting resources such as light, water and nutrients. However, species differ in the degree of phenotypic plasticity. Regarding light intensity heterogeneity, species can be classified as "shadow tolerant" if they can regenerate under forest canopy, and "shadow intolerant" if they cannot maintain a seedling bank under such conditions $[11,17]$. On the other hand, Mediterranean species have developed several mechanisms of tolerance to water stress and low nutrient availability. Within this framework of resources variability, plasticity of antiherbivore defenses may play an important role for plant survival, especially during the juvenile period (seedling stage).

$Q$. ilex and $Q$. cerrioides have similar properties: slow growth, deep roots, resprouting ability after disturbances, but differ in leaf duration: $Q$. cerrioides is a winter-deciduous and $Q$. ilex is an evergreen. Differences in leaf life span may imply differences in the use of light, water and nutrients. Ever- greenness has been considered as an adaptation to nutrient and water poor environments [5], whereas deciduousness implies a shorter photosynthetically active period that must be compensated by a high light-saturated assimilation rate, which requires large nutrient and water availabilities [18].

We aim to study the phenotypic plasticity of CT depending on the availability of several abiotic resources (light, nutrients and water) in order to establish their influence on chemical defense against herbivores on two Quercus species contrasting in leaf life span. The three different resources vary in the natural environments where these species grow: light depending on canopy closure, nutrients depending on soil fertility and water subject to inter-year natural variation.

\section{MATERIAL AND METHODS}

\subsection{Experimental design}

Acorns of $Q$. ilex and $Q$. cerrioides were set under optimal conditions to promote germination and, once germinated, were transferred to individual plastic pots filled with $1.5 \mathrm{~L}$ of oligotrophic substratum (TKS1, Floragard Vertrieb GmbH, Oldenburg, Germany). Pots were placed outdoors in a garden of the Autonomous University of Barcelona under a transparent plastic roof $6 \mathrm{~m}$ high, providing almost natural atmospheric conditions but excluding rainfall. Recent emerged seedlings were assigned to different light, nutrients and watering treatments factorially combined. Each combination of light, water and nutrients availability included 21 seedlings per species and was repeated in three replications (three separate blocks, see [20] for further details on this experiment). For the light treatment the photosynthetic active radiation (PAR) was reduced by suspending a shade cloth to $8 \%$ of the naturally incident PAR for the low-light environment (L8) and to $36 \%$ of the incident PAR for the high light environment (L36), in order to reproduce the light environment of Quercus forests with low (L36) and high (L8) canopy cover [19]. Plants were watered every two weeks at two regimes, a low regime (W500 = $\left.500 \mathrm{~mm} \mathrm{y}^{-1}\right)$ and a high water regime $\left(\mathrm{W} 800=800 \mathrm{~mm} \mathrm{y}^{-1}\right)$. High and low water regimes are above and below the yearly average precipitation of $600 \mathrm{~mm} \mathrm{~m}^{-2} \mathrm{y}^{-1}$ that is registered on the distribution area of both species. To provide realistic conditions, the annual amount of water was distributed monthly following the Mediterranean seasonal pattern, characterized by a rainy spring and fall and a dry summer. The fertilization treatment consisted of a low nutrient level $(\mathrm{N}-$ ) for the plants growing in the non-amended oligotrophic substrate, whereas for the high nutrient level $(\mathrm{N}+)$ the substrate was supplied at the beginning of the experiment with $48 \mathrm{~kg} \mathrm{~N} \mathrm{ha}^{-1}, 19 \mathrm{~kg} \mathrm{P} \mathrm{ha}^{-1}$ and $58 \mathrm{~kg} \mathrm{~K} \mathrm{ha}^{-1}$.

At the end of the experiment, $12 Q$. ilex and $12 Q$. cerrioides seedlings of each treatment were randomly chosen (four per replication) and total biomass was separated into leaves, stems and roots. Dry weight of roots, shoots, and leaves was calculated after drying at $60{ }^{\circ} \mathrm{C}(72 \mathrm{~h})$ and total plant biomass was considered as an estimate of the net growth of seedlings. For the two species, leaves of the four seedlings harvested for each treatment and replication were pooled to obtain an amount sufficient for grinding and analyzing. 
Table I. Results of ANOVA analysis for the effects of light, water and species on leaf CT, N and growth under a fixed level of nutrients (N-). The sources of variation were light levels (L8, L36), water levels (W500, W800) and species (Q. ilex, Q. cerrioides) $(d f=$ degrees of freedom).

\begin{tabular}{lccccccc}
\hline & & \multicolumn{2}{c}{ Condensed Tannins } & \multicolumn{2}{c}{ Nitrogen } & \multicolumn{2}{c}{ Growth } \\
\cline { 3 - 7 } Source of variation & $d f$ & $F$ value & $P$ value & $F$ value & $P$ value & $F$ value & $P$ value \\
\hline Light & 1 & 23.5 & $\mathbf{0 . 0 0 0 2}$ & 283.53 & $\mathbf{0 . 0 0 0 1}$ & 56.5 & $\mathbf{0 . 0 0 0 3}$ \\
Water & 1 & 0.6 & 0.8088 & 3.50 & 0.0810 & 9.5 & 0.1014 \\
Species & 1 & 77.1 & $<\mathbf{0 . 0 0 0 1}$ & 31.50 & $\mathbf{0 . 0 0 0 1}$ & 0.4 & 0.5556 \\
Light $\times$ Water & 1 & 0.5 & 0.4823 & 4.28 & 0.0564 & 0.2 & 0.6712 \\
Light $\times$ Species & 1 & 16.4 & $\mathbf{0 . 0 0 1 1}$ & 6.06 & $\mathbf{0 . 0 2 6 4}$ & 2.5 & 0.1611 \\
Water $\times$ Species & 1 & 0.0 & 0.8879 & 0.79 & 0.3895 & 0.4 \\
Light $\times$ Water $\times$ Species & 1 & 0.2 & 0.6358 & 2.18 & 0.1604 & 0.8 & 0.5721 \\
\hline
\end{tabular}

\subsection{Chemical analyses}

Soluble CT were extracted from $20 \mathrm{mg}$ of leaf powder with $70 \%$ acetone. Tubes containing the sample and the acetone were sonicated three times for 1 min allowing the tubes to cool for three minutes between successive sonications. After centrifugation, the extract was assayed with the butanol/HCl method [35] modified as in [30]. Briefly, $0.5 \mathrm{~mL}$ of the extract were mixed with $3 \mathrm{~mL}$ butanol$\mathrm{HCl}$ (95:5) and $0.1 \mathrm{~mL}$ of ferric reagent (ferric ammonium sulfate in $2 \mathrm{~N} \mathrm{HCl}$ ) and maintained in a boiling bath for $60 \mathrm{~min}$. The absorbance was read at $550 \mathrm{~nm}$ after cooling the tube. Non-heated replicate tubes for each extract were used as anthocyanin blank by substracting its absorbance from the absorbance of the heated tubes. The CT content on a dry weight basis was estimated using an $\mathrm{E}^{1 \%, 1 \mathrm{~cm}, 550 \mathrm{~nm}}$ of $460[30,35]$. CT analyses were done in duplicate. Nitrogen concentrations were determined in an elemental analyzer (Carlo Erba Instruments EA 1108 CHNS/O, Milan, Italy).

\subsection{Statistics}

During the experiment a high rate of seedling mortality was observed for the low water-high nutrient combination (see [20]). This situation lead to the original experimental design becoming unbalanced. For this reason, statistical analyses to asses the effects of watering and nutrients were performed independently. Nutrient treatment effects were assessed on the W800 water regime using a three way ANOVA with species, light and nutrients as fixed factors. Water treatment was assessed only for the low nutrient treatment with species, light and water as fixed factors. Differences among levels of each main factor were tested by Fisher's PLSD.

\section{RESULTS}

Leaf CT concentrations were significantly higher (ca 7 times) in $Q$. ilex than in $Q$. cerrioides (Tab. I, Fig. 1A). Neither water nor nutrient treatment had an effect on CT (Tabs. I and II), whereas light enhanced CT concentrations in the two species (Tabs. I and II). However, the interaction light $\times$ species (Tab. I, Fig. 1A) revealed that this increase was larger in Q. ilex $(146 \%)$ than in Q. cerrioides $(57 \%)$.

Conversely to leaf $\mathrm{CT}$ concentration, $\mathrm{N}$ concentrations were higher (1.15 times) in $Q$. cerrioides than in $Q$. ilex. N concentration significantly varied with nutrient and light availability

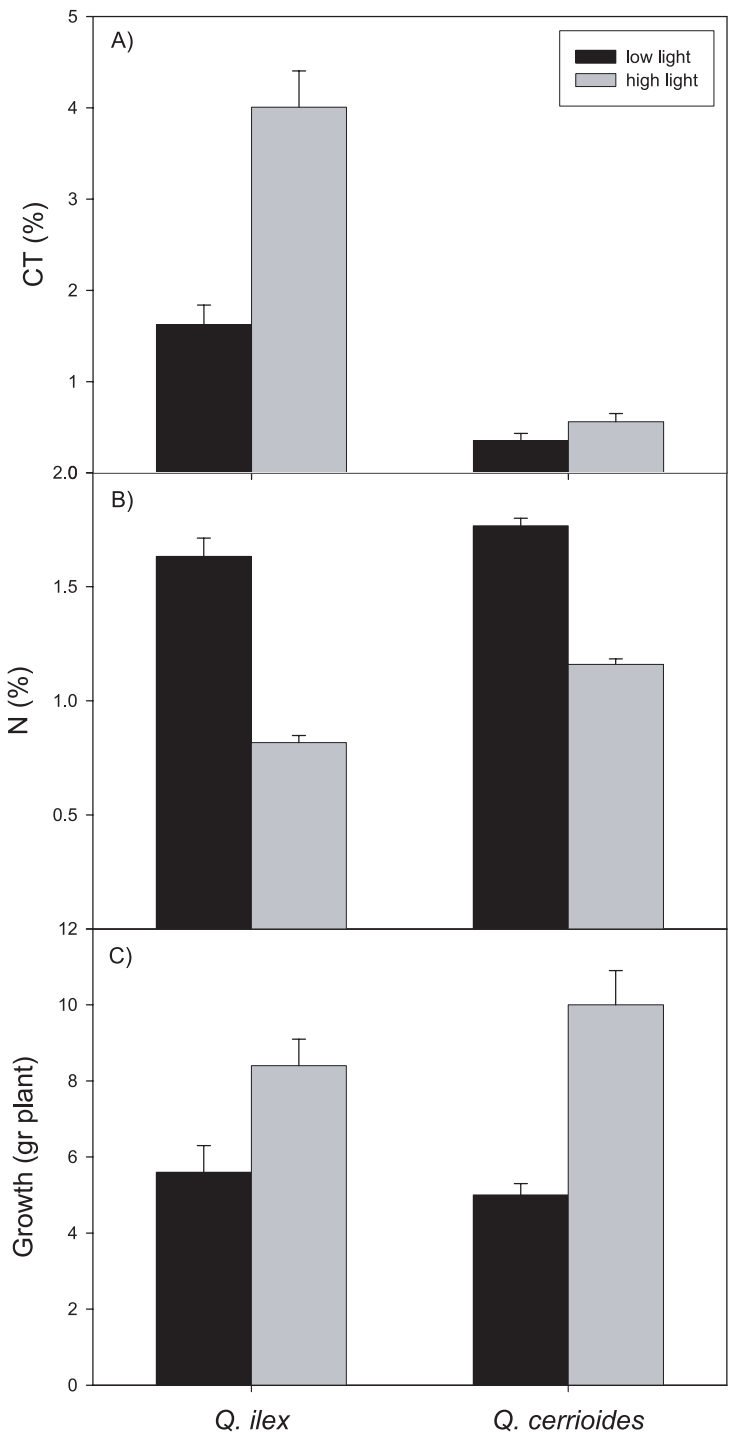

Figure 1. Mean $(\% \pm \mathrm{SE}) \mathrm{CT}$ concentration (A), N concentration (B) and growth (C) for $Q$. ilex and $Q$. cerrioides in the two light levels tested (low light-L8 and high light-L36) under low nutrient treatment $(n=6)$. Growth is expressed as final weight (gr plant) of plants grown from seeds. 
Table II. Results of ANOVA analysis for the effects of light, nutrients and species on leaf CT, N and growth under a fixed level of water (W800). The sources of variation are light levels $(\mathrm{L} 8, \mathrm{~L} 36)$, nutrient levels $(\mathrm{N}-, \mathrm{N}+)$ and species $(Q$. ilex, $Q$. cerrioides $)(d f=$ degrees of freedom).

\begin{tabular}{lccccccc}
\hline & & \multicolumn{2}{c}{ Condensed Tannins } & \multicolumn{2}{c}{ Nitrogen } & \multicolumn{2}{c}{ Growth } \\
\cline { 3 - 8 } Source of variation & $d f$ & $F$ value & $P$ value & $F$ value & $P$ value & $F$ value & $P$ value \\
\hline Light & 1 & 26.25 & $\mathbf{0 . 0 0 0 1}$ & 188.91 & $\mathbf{0 . 0 0 0 1}$ & 10.3 & $\mathbf{0 . 0 2 6 6}$ \\
Nutrients & 1 & 0.0 & 0.9492 & 6.69 & $\mathbf{0 . 0 1 9 9}$ & 1.2 & 0.2839 \\
Species & 1 & 227.0 & $<\mathbf{0 . 0 0 0 1}$ & 5.35 & $\mathbf{0 . 0 3 4 3}$ & 0.8 & 0.3917 \\
Light $\times$ Nutrients & 1 & 0.6 & 0.4305 & 0.46 & 0.5060 & 0.3 & 0.7760 \\
Light $\times$ Species & 1 & 7.5 & $\mathbf{0 . 0 1 4 6}$ & 1.50 & 0.2384 & 1.3 & 0.3052 \\
Nutrient $\times$ Species & 1 & 0.1 & 0.8124 & 0.91 & 0.3550 & 2.2 & 0.1659 \\
Light $\times$ Nutrient $\times$ Species & 1 & 1.8 & 0.2024 & 2.24 & 0.1539 & 1.9 & 0.1916 \\
\hline
\end{tabular}

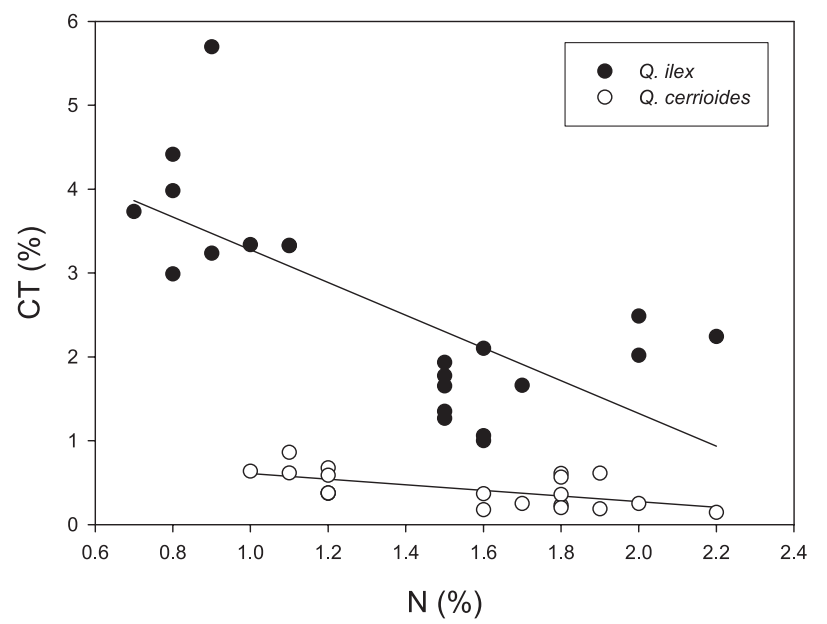

Figure 2. CT concentration as a function of $\mathrm{N}$ concentration in leaves of $Q$. ilex (solid circle) and $Q$. cerrioides (open circle). Data for different treatments were pooled. The regression equations were: for $Q$. ilex $\% \mathrm{CT}=5.229-1.952 * \% \mathrm{~N} ; R^{2}=.502, P=0.0003$ ), and for $Q$. cerrioides $\left.\% \mathrm{CT}=0.944-0.335 * \% \mathrm{~N} ; R^{2}=0.352, P=0.0058\right)$.

(Tabs. I and II). Seedlings grown under the low nutrient level had a lower leaf $\mathrm{N}$ concentration than those of the high nutrient level (respectively, $\mathrm{N}=1.38 \pm 0.13 \%$ vs. $\mathrm{N}=1.54 \pm 0.14 \%$ ). In the two species, light decreased $\mathrm{N}$ concentrations with a larger reduction in Q. ilex $(99 \%)$ than in Q. cerrioides $(57 \%)$ (Fig. 1B).

Growth, measured as final biomass of plants grown from seeds, did not differ between $Q$. ilex and $Q$. cerrioides at the end of the experiment $(Q$. ilex $=7.0 \pm 0.6 \mathrm{~g}$ and $Q$. cerrioides $=$ $7.3 \pm 0.9 \mathrm{~g})$. In both species growth was enhanced by light availability (Tabs. I and II, Fig. 1C), whereas it was affected neither by nutrient nor water availability (Tabs. I and II).

CT were negatively correlated with $\mathrm{N}$ concentration (Fig. 2) for both species. The relation was steepest for $Q$. ilex, as reflected by light $\times$ species interaction (Tabs. I and II), indicating that this evergreen species with higher concentration has more phenotypic plasticity in carbon allocation to CT.

\section{DISCUSSION}

Average leaf concentrations of CT measured in $Q$. ilex $(2.8 \%)$ are lower than the values reported for the species (2\% [9], 3.6-8.1\% [10], 8.7\% [37]), partly because they were measured under low or moderate light availability, but higher than the low amounts reported in other studies (0.5\% [31]). The lower leaf CT in $Q$. cerrioides were at the low range of concentrations found among Quercus species [32]. Whereas we found higher CT in the evergreen species, other authors did not find any difference in another pair of cooccurring evergreen and deciduous oaks, such as $Q$. ilex and Q. pubescens [45].

The difference in $\mathrm{N}$ concentrations between $Q$. cerrioides and $Q$. ilex was small, only 1.15 times more in the deciduous than in the evergreen species, but when taking into account only the $36 \%$ PAR ligh level, $Q$. cerrioides N concentrations were 1.41 times higher. This difference has also been described for other pairs of co-occurring evergreen and deciduous oak species: $Q$. pubescens had 1.6 times more $\mathrm{N}$ than $Q$. ilex $[16,45]$, and the deciduous $Q$. faginea had 1.6 times more $\mathrm{N}$ than the evergreens $Q$. ilex and $Q$. coccifera [13].

The leaf chemistry reflects how plants with longer leaf lifetimes invest more resources to better defend leaves that are more exposed to herbivore attack [15]. Species with longer leaf lifetimes tend to be sclerophyllus, and have lower SLA and leaf $\mathrm{N}$ to maximize unpalability $[2,18]$, as in the case of the pair of oaks we studied.

We expected higher CT concentrations under high light because higher photosynthesis, and consequently carbon supply, reduces $\mathrm{C} / \mathrm{N}$ ratio (carbon nutrient balance hypothesis) or either because, although growth is also stimulated, light promotes a stronger stimulation on carbon acquisition by photostynthesis than on carbon demand for growth (growth differentiation balance hypothesis), and more carbon is available for allocation to CT. The two species studied had the predicted response to light in agreement with the meta-analysis of Koricheva et al. [28] and the review of Peñuelas and Estiarte [34]. Light availability is, thus, confirmed as a very strong determinant of CT concentrations. 
We expected lower CT concentrations increasing nutrient availability because of an increase in $\mathrm{N}$ concentration, and a decrease in $\mathrm{C} / \mathrm{N}$ ratio (carbon nutrient balance hypothesis), parallel to an increase in carbon demand for growth higher than the positive effects of better nutrition on photosynthetic carbon acquisition (growth differentiation balance hypothesis). Decreases in phenolics with nutrient availability were found in the meta-analysis of Koricheva et al. [28] and the review of Peñuelas and Estiarte [34]. However, the lack of effects on CT of the fertilization treatment reported in our study disagrees with these predictions. Some Quercus have also shown results in disagreement with these expectations, such as the lack of effect of $\mathrm{N}$ fertilization reported for $Q$. rubra leaf CT [27], but others have been reported to increase leaf $\mathrm{N}$ and decrease CT in response to soil fertilization, as was the case of Q. coccifera [22].

Although leaf $\mathrm{N}$ reduction by increasing light availabilities has often been considered as a consequence of dilution by more carbon fixed, surprisingly the meta-analysis by Koricheva et al. [28] concluded that there was an absence of light effects on leaf N. Koricheva's conclusion was based on 21 observations. Further revisions are needed to reconsider this conclusion, which contradicts general considerations on the basis of ecological stoichiometry (see [44]) and the effect of light found for both Quercus species. In contrast with CT, where no effect of nutrient treatment was found, higher $\mathrm{N}$ concentrations were found in leaves at high $\mathrm{N}$ treatment, a result which rules out the absence of effect of a mild level of fertilizer (7\% increase in soil $\mathrm{N}$ availability) on leaf chemistry. However, the effects of nutrient treatment were restricted to leaf $\mathrm{N}$ concentration because growth was not affected by fertilization (Tab. II). Similarly, neither several morphological parameters [14, 20], nor, as mentioned, were CT affected (Tab. II).

Horner [26] proposed a non-linear effect of water deficit on carbon-based secondary compounds depending on the intensity of the deficit. Moderate water deficits, causing a stronger decline in growth than in photosynthesis, will result in carbon accumulation that can be allocated to carbon-based secondary compounds, whereas severe deficits with stronger effects on photosynthesis than growth will reduce carbon-based secondary compounds. Consequently, no clear pattern can be found when experiments do not include a wide range of water stress. Similarly to our results, Koricheva's meta-analysis [28] resulted in no effects of water deficit on carbon-based secondary compounds nor in N. Bussotti et al. [9] also found no differences in leaf CT among $Q$. ilex stands growing in sites with contrasting water availability, and a lack of relation among water availability and leaf $\mathrm{N}$ has also been described for $Q$. ilex and $Q$. faginea along a rainfall gradient, but at the humid extreme of the gradient $Q$. coccifera had more leaf $\mathrm{N}$ [13]. Moreover, contrasting results have been described at the individual level in Ceratonia siliqua seedlings, a Mediterranean evergreen, where water stress increased CT and reduced $\mathrm{N}$ in young leaves, but no effects were found in old leaves [29]. Differences in intensity of effects among organs were also described for Lotus corniculatus where water stress reduced CT, but the reduction was more obvious in roots than in leaves [12].
The carbon nutrient balance hypothesis [9], which relates the concentration of carbon-based secondary compounds to the balance between carbon and $\mathrm{N}$ is supported by the negative correlation we found between $\mathrm{N}$ and $\mathrm{CT}$ (Fig. 2). In our experiment the relation was mainly driven by light and was not found within plants of the same light level, probably due to the mild level of fertilizer applied, but the same relation has been found in other experiments that span a wider range of fertilization levels [8]. The light treatment at 36\% PAR is the value below which growth of $Q$. ilex is limited by light, and above which it is limited by water stress in a large part of the area of distribution of the species [38]. Growth of $Q$. ilex is not limited by carbon supply at this light intensity and excess carbon can be invested in secondary compounds without diverting resources from growth. On the other hand, Q. cerrioides exhibited greater plasticity in response to light intensity in morphological characteristics, e.g. root/shoot [20], but not in growth (Tabs. I and II), whereas $Q$. ilex exhibited greater plasticity in leaf CT. Our results seem to point to there being a trade-off between morphologic plasticity and CT plasticity, because whereas $Q$. cerrioides favours allocation to roots for nutrient and water acquisition, $Q$. ilex increases leaf protection by increasing leaf CT. The lack of effects of nutrient treatment on growth and CT does not allow the trade-off between growth and differentiation to be tested besides the evidence that increases in carbon acquisition at high light increase the carbon allocation to both biomass and CT.

In forests, perturbations that open the canopy and modify the light environment can modify foliar chemistry and, consequently, effect herbivore performance. Different studies have outlined the importance of environmental conditions to finally determine herbivory intensity $[25,46]$. Although we did not find effects of fertilization treatments besides leaf $\mathrm{N}$, it is likely that perturbations that modify nutrient availability, such as forest fires, can potentially modify leaf chemistry and affect herbivore performance. However, published results have failed to show such effects: Rieske [39] has shown increased $\mathrm{N}$ in $Q$. prinus seedlings growing after wildfire, but no changes in CT were detected, Rieske et al. [6,40] described no effects of prescribed fire on CT of canopy leaves of $Q$. prinus and $Q$. coccinea, and Adams and Rieske [1] reported that prescribed fire history affected neither N nor CT in Q. alba seedlings, although there was between year variation in both parameters that authors attributed to drought. Such changes in leaf chemistry after forest fires are likely to affect plant-herbivore interactions.

The importance of CT in plant-herbivore interactions has been well established in studies involving woody species and small ruminants widely distributed in the Mediterranean region [42], and has been tested for $Q$. ilex [33]. The intake of some Mediterranean shrubs and trees, such are $Q$. calliprinos, Pistacia lentiscus and C. siliqua, is limited by its high tannin content [43]. However, the tolerance of herbivores to tannins is species-specific: some species (e.g. sheep) are more sensitive than others, which may even derive some benefit from high tannin diets (e.g. goats) [33]. Moderate concentrations (2-4\%) of CT exert some beneficial effects on sheep nutrition, whereas diets with high concentrations (6-12\%) depress 
voluntary feed intake, digestive efficiency and animal productivity [3]. Q. ilex plants growing at $36 \%$ PAR had concentrations of ca $4 \%$, at the edge of concentrations with negative effects on nutrition, but CT in $Q$. cerrioides were far from that point. Moreover, the decrease in nutritional quality of leaves grown under high light is amplified because the effects on $\mathrm{CT}$ are opposite to the effects on $\mathrm{N}$, and foliage quality depends on benefits (e.g. nitrogen acquisition) and costs (e.g. plant defenses ingestion) for the herbivore [4]. Consequently, disturbances that open the canopy and promote less shaded environments, including herbivory itself, cause an increase in CT concentration that can negatively affect the nutrition of the more sensitive species.

Espelta et al. [21] reported that sheep ate more post-fire resprouts of $Q$. cerrioides than resprouts of $Q$. ilex, which can be attributed to the higher CT in the evergreen species. Furthermore, although under controlled conditions survival of seedlings at 36\% PAR was the same for both species and survival at $8 \%$ PAR was higher for $Q$. cerrioides than for $Q$. ilex [20], field observations in mixed forests of these species commonly show a higher abundance of $Q$. ilex than $Q$. cerrioides seedlings [14]. We hypothesize that this fact can be due to higher herbivorism in $Q$. cerrioides, facilitated by its lower CT content and by its lower CT phenotypic plasticity to light availability, an hypothesis that must be confirmed by further studies.

Acknowledgements: We greatfully acknowledge funding from the INTERREG III A project (I3A-1-100-E), Patronat Metropolità del Parc de Collserola, Spanish Government grants REN200304871/GLO, Catalan government grant SGR2005-00312, the EC Integrated FP6 ALARM (GOCE-CT-2003-506675) Project, and a Fundación BBVA 2004 grant. Marc Estiarte acknowledges financial support from the Spanish Ministerio de Educación y Ciencia (Ramon y Cajal contract).

\section{REFERENCES}

[1] Adams A.S., Rieske L.K., Prescribed fire affects white oak seedling phytochemistry: implications for insect herbivory, For. Ecol. Manage. 176 (2003) 37-47.

[2] Aerts R., The advantages of being evergreen, Trends Ecol. Evol. 10 (1995), 402-407.

[3] Aerts R.J., Barry T.N., McNaab W.C., Polyphenols and agriculture: beneficial effects of proanthocyanidins in forages, Agric. Ecosyst. Environ. 75 (1999) 1-12.

[4] Belovsky G.E., Schmitz O.J., Mammalian herbivore optimal foraging and the role of plant defenses, in: Palo R.T., Robbins C.T. (Eds.), Plant defenses against mammalian herbivory, CRC, Boca Raton, 1991, pp. 1-28.

[5] Berendse F., Competition between plant populations at low and high nutrient supplies, Oikos 71 (1994) 253-260.

[6] Bernays E.A., Cooper Driver G., Bilgener M., Herbivores and plant tannins, in: Begon M., Fitter A.H., Ford E.D., MacFadyen A. (Eds.), Advances in Ecological Research, Vol. 19. Academic Press, London, 1989, pp. 263-302.
[7] Bryant J.P., Chapin III F.S., Klein D.R., Carbon/nutrient balance of boreal plants in relation to vertebrate herbivory, Oikos 40 (1983) 357-368.

[8] Burns A.E., Gleadow R.M., Woodrow I.E., Light alters the allocation of nitrogen to cyanogenic glycosides in Eucalyptus cladocalyx, Oecologia 133 (2002) 288-294.

[9] Bussotti F., Bettini D., Grossoni P., Mansuino S., Nibbi R., Soda C., Tani C., Structural and functional traits of Quercus ilex in response to water availability, Environ. Exp. Bot. 47 (2002) 11-23.

[10] Cabiddu A., Decandia M., Sitzia M., Molle G., A note on chemical composition and tannin content of some Mediterranean shrubs browsed by Sarda goats, Cah. Options Médit. 52 (2000) 175-178.

[11] Canham C.D., Different responses to gaps among shade-tolerant tree species, Ecology 70 (1989) 548-550.

[12] Carter E.B., Theodorou M.K., Morris P., Responses of Lotus corniculatus to environmental change. 2. Effect of elevated $\mathrm{CO}_{2}$, temperature and drought on tissue digestion in relation to condensed tannin and carbohydrate accumulation, J. Sci. Food Agric. 79 (1999) 1431-1440.

[13] Castro-Díez P., Villar-Salvador P., Pérez-Rontomé C., MaestroMartínez M., Montserrat-Martí G., Leaf morphology and leaf chemical composition in three Quercus (Fagaceae) species along a rainfall gradient in NE Spain, Trees 11 (1997) 127-134.

[14] Cortés, P., Distribución y dinámica de un Quercus caducifolio (Q. cerrioides Wilk et Costa) y uno perennifolio $(Q$. ilex $\mathrm{L}$.) en Catalunya. Análisis de la ecología de la reproducción, la respuesta de las plántulas a factores ambientales y la respuesta a las perturbaciones, M.Sc. thesis, Universitat Autònoma de Barcelona, Barcelona, 2003.

[15] Coley P.D., Bryant J.P., Resource availability and plant antiherbivore defense, Science 230 (1985) 895-899.

[16] Damesin C., Rambal S., Joffre R., Co-occurrence of trees with different leaf habit: a functional approach on Mediterranean oaks, Acta Oecol. 19 (1998) 195-204.

[17] Denslow J., Tropical rainforest gaps and tree species diversity, Annu. Rev. Ecol. Syst. 18 (1987) 431-451.

[18] Eamus D., Ecophysiological traits of deciduous and evergreen woody species in the seasonally dry tropics, Trends Ecol. Evol. 14 (1999) 11-16.

[19] Espelta J.M., Riba M., Retana J., Patterns of seedling recruitment in West Mediterranean Quercus ilex L. forests as influenced by canopy development, J. Veg. Sci. 6 (1995) 645-672.

[20] Espelta J.M., Cortes P., Mangiron M., Retana J., Differences in biomass partitioning, leaf nitrogen content, and water use efficiency (delta C-13) result in similar performance of seedlings of two Mediterranean oaks with contrasting leaf habit, Ecoscience 12 (2005) 447-454

[21] Espelta J.M., Habrouk A., Retana J., Response to natural and simulated browsing of two Mediterranean oaks with contrasting leaf habit after a wildfire, Ann. For. Sci. 63 (2006) 441-447.

[22] Glyphis J.P., Puttick G.M., Phenolics, nutrition and insect herbivory in some garrigue and maquis plant species, Oecologia 78 (1989) 259-263.

[23] Harborne, J.B., Role of phenolic secondary metabolites in plants and their degradation in nature, in: Cadisch G., Giller K.E. (Eds.), Driven by nature. Plant litter quality and decomposition, CABI Publishing, Oxon, 1999, pp. 67-74.

[24] Herms D.A., Mattson W.J., The dilemma of plants: to grow or defend, Q. Rev. Biol. 67 (1992) 283-335.

[25] Heuze P., Schnitzler A., Klein F., Consequences of increased deer browsing winter on silver fir and spruce regeneration in the Southern Vosges mountains: Implications for forest management, Ann. For. Sci. 62 (2005) 175-181. 
[26] Horner J.D., Nonlinear effects of water deficits on foliar tannin concentration, Biochem. Syst. Ecol. 18 (1990) 211-213.

[27] Kinney K.K., Lindroth R.L., Jung S.M., Nordheim E.V., Effects of $\mathrm{CO}_{2}$ and $\mathrm{NO}_{3}^{-}$availability on deciduous trees: phytochemistry and insect performance, Ecologia 78 (1997) 215-230.

[28] Koricheva J., Larsson S., Haukioja E., Keinänen M., Regulation of woody plant secondary metabolism by resource availability: hypothesis testing by means of meta-analysis, Oikos 83 (1998) 212-226.

[29] Kouki M., Manetas Y., Resource availability affects differentially the levels of gallotannins and condensed tannins in Ceratonia siliqua, Biochem. Syst. Ecol. 30 (2002) 631-639.

[30] Makkar H.P.S., Goodchild A.V., Quantification of tannins: a laboratory manual. International Center for Agricultural Research in the Dry Areas (ICARDA), Aleppo, 1996.

[31] Makkar H.P.S., Dawra R.K., Singh S., Tannin levels in leaves of some oak species at different stages of maturity, J. Sci. Food. Agric. 54 (1991) 513-519.

[32] Martin J.S., Martin M.M., Tannin assays in ecological studies: lack of correlation between phenolics, proanthicyanidins and proteinprecipitating constituents in mature foliage of six oak species, Oecologia 54 (1982) 205-211.

[33] Narjisse H., Elhonsali L.A., Olsen J.D., Effects of oak (Quercus ilex) on digestion and nitrogen balance in sheep and goats, Small Rumin. Res. 18 (1995) 201-206.

[34] Peñuelas J., Estiarte M., Can elevated $\mathrm{CO}_{2}$ affect secondary metabolism and ecosystem function? Trends Ecol. Evol. 13 (1998) $20-24$.

[35] Porter L.J., Hrstich L.N., Chan B.G., The conversion of procyanidins and prodelphinidins to cyanidin and delphinidin, Phytochem. 25 (1986) 223-230.

[36] Quézel P., Médail F., Écologie et biogéographie des forêts du bassin méditerranéen, Elsevier SAS, Paris, 2003.
[37] Rebolé A., Fiber and tannins of some agricultural and forest byproducts. Inclusion of these parameters in the prediction of in vitro digestibility, J. Agric. Food Chem. 42 (1994) 739-743.

[38] Retana J., Espelta J.M., Gracia M., Riba M., Seedling recruitment, in: Rodà F., Retana J., Gracia C.A., Bellot J. (Eds.), Ecology of Mediterranean evergreen oak forests, Springer Verlag, Berlin, 1999, pp. 89-101.

[39] Rieske L.K., Wildfire alters oak growth, foliar chemistry, and herbivory, For. Ecol. Manage. 168 (2002) 91-99.

[40] Rieske L.K., Housman H.H., Arthur M.A., Effects of prescribed fire on canopy foliar chemistry and suitability for an insect herbivore, For. Ecol. Manage. 160 (2002) 177-187.

[41] Sardans J., Rodà F., Peñuelas J., Phosphorus limitation and competitive capacities of Pinus halepensis and Quercus ilex subsp. rotundifolia on different soils, Plant Ecol. 174 (2004) 305-317.

[42] Silanikove N., Gilboa N., Nir I., Perevolotsky A., Nitsan Z., Effect of daily supplementation of polyethylene glycol on intake and digestion of tannin-containing leaves (Quercus calliprinos, Pistacia lentiscus and Ceratonia siliqua) by goats, J. Agric. Food Chem. 44 (1996) 199-205.

[43] Specht R.L., Structure and functional response of ecosystems in the Mediterranean climate of Australia, in: Di Castri F., Mooney H.A. (Eds.), Mediterranean-type ecosystems: Origen and structure, Chapman \& Hall, London, 1973, pp. 113-120.

[44] Sterner R.W., Elser J.J., Ecological Stoichiometry: The Biology of Elements from Molecules to the Biosphere, Princeton University Press, Princeton, 2002.

[45] Tognetti R., Johnson J.D., Michelozzi M., Raschi, A., Response of foliar metabolism in mature trees of Quercus pubescens and Quercus ilex to long-term elevated $\mathrm{CO}_{2}$, Env. Exp. Bot. 39 (1998) 233-245.

[46] Vila B., Guibal F., Torre F., Martin J.L., Can we reconstruct deer browsing history and how? Lessons from Gaultheria shallon Pursh, Ann. For. Sci. 62 (2005) 153-162.

[47] Zavala M.A., Espelta J.M., Retana J., Constraints and trade-offs in Mediterranean plant communities: The case of holm oak-Aleppo pine forests, Bot. Rev. 66 (2000) 119-149. 